\title{
'The Voice in the Mirror'. Michael Jackson: From a Vocal Identity to its Double in Sound
}

Isabelle Stegner-Petitjean

\section{(2) OpenEdition}

\section{Journals}

Electronic version

URL: https://journals.openedition.org/volume/3851

DOI: 10.4000/volume.3851

ISSN: 1950-568X

This article is a translation of:

"The Voice in the Mirror". Michael Jackson : d'une identité vocale à sa mise en image sonore - URL :

https://journals.openedition.org/volume/2760 [fr]

Publisher

Association Mélanie Seteun

\section{Printed version}

Date of publication: 15 December 2011

Number of pages: $222-253$

ISBN: 978-2-913169-30-2

ISSN: $1634-5495$

\section{Electronic reference}

Isabelle Stegner-Petitjean, "'The Voice in the Mirror'.

Michael Jackson: From a Vocal Identity to its Double in Sound", Volume! [Online], $8: 2$ | 2011, Online since 15 December 2013, connection on 24 March 2023. URL: http://journals.openedition.org/volume/ 3851 ; DOl: https://doi.org/10.4000/volume.3851

This text was automatically generated on 24 March 2023.

All rights reserved 


\section{'The Voice in the Mirror'. Michael Jackson: From a Vocal Identity to its Double in Sound}

Isabelle Stegner-Petitjean

2011 young researcher IASPM French-Speaking

Europen branch prize*

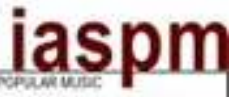

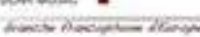

Links to listen to the musical excerpts: http:// www.seteun.net/spip.php?article271 
1

MICHAEL JACKSON IS AN ARTIST whose career became, with a definite paroxysm, the emblem of pop music in a trans-cultural and technological twentieth century. He brought to a certain height the paradigms of the international pop aestheticism which are the high-scale impact and broadcasting and shaped an image representative of the synthesis of artistic expression and trans-racial figures which make up the cement of pop music.

The taking over of esthetical influences that impacted the singer, strengthened by

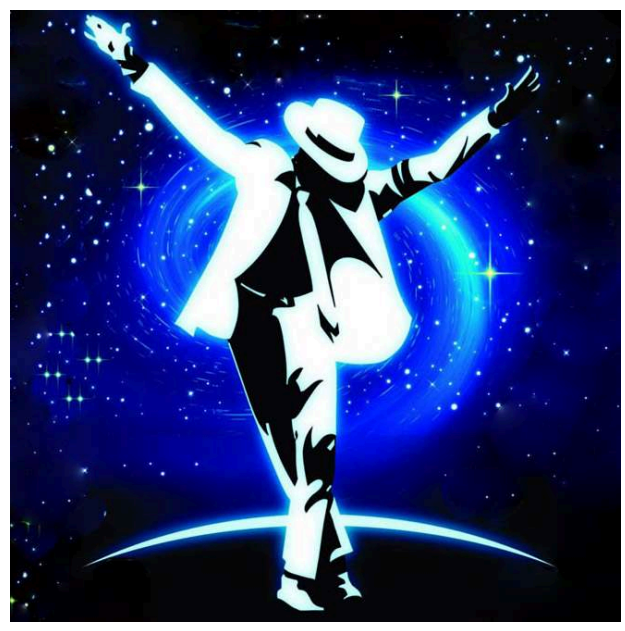
a continuous spirit of innovation, was at the root of the creation of an artistic identity in its own right, medium of an expressive authenticity which, on a vocal level, is comparable to what we can call a personality.

Not limiting himself to any aesthetical fetters, the artist, all along his career, tried to develop and renew an obvious expressive plurality. Plurality which, combining spoken and sung voices, voiced and non-voiced sounds, oral percussions, bruitism, breathing games and voiced choreographies, was taken over and centralized by a body with a great phonic presence in the musical sphere, confirming what Roland Barthes said: "In pop music, there is the physical component which is so important for this type of counter-culture. There is a new relation to the body, which we need to defend". (Barthes,1981: 164)

But apart from the physical aspect, we will see that this plurality is underpinned by a vocal work directed by a teacher coming from the lyrical world, Seth Riggs, as well as by the spontaneous use of more original or less aestheticized forms of expression.

3 Concerned that his vocal personality shouldn't be diluted or diminished, Michael Jackson - conscious of the reach and responsibility of recording in the media - took a high interest in its fixing and the shaping of what had to be not only his sonorous image but also his recorded double. In doing so, he appointed, for his whole career, a figurehead sound-engineer, Bruce Swedien, who was in a parallel quest of sound authenticity and whose technical choices, guided by this quest, will make up the second part of this study.

But first, we propose to study the components of Michael Jackson's vocal identity, through technical criteria but also in the light of a work on the tone which made this notion of identity develop into the more colorful notion of personality.

\section{Michael Jackson's voice: from identity to personality}

\section{Cradle and beginnings}

4 Michael Jackson's vocal identity took its roots in his youth's music career. Endowed with a definite vocal expressiveness since his boyhood (which made even professionals ${ }^{1}$ doubt his young age), and a gift for dancing, Michael Jackson initiated his artistic career - which lasted almost 50 years - by a first very dense amateur career starting at the age of 5 , with daily evening rehearsals, along with competitions and frequent

Volume !, $8: 2$ | 2011 
shows. At this time, he absorbed the classical and country music his Mom, a clarinetist, was listening to, but also Little Richard, Chuck Berry, The Temptations, Aretha Franklin, Fats Domino and other rhythm and blues singers. The goal the family set themselves during these competitions was not limited to "taking up" a famous title but to bring the musical, expressive or scenic element which will create the demarcation.

That is how his training started, under the aegis of a strict and efficient father, leading to the signature of a contract with the Motown label at the age of 11:

" The five young brothers [...] impressed Berry Gordy with their precocious professionalism, discipline, and raw talent at their audition in the summer of 1968 ». (Smith, 1999 : 229)

6 The "artist development" program of the Jackson 5 group was then drawn up according to the Hitsville tradition, with every aspect of the performance or the public image being under control. Motown's writers and producers created a repertoire of specific songs and covers ${ }^{2}$ of various aestheticisms for the Jackson 5 , without letting them the slightest possibility to propose one of their own compositions, and thus feeding little by little the reasons for the breaking-off in 1976.

While signing with the Epic Records label, at an age when others are only starting their careers, Michael Jackson necessarily felt the deep need to create his style. Having made during these seven years the most of the expressive, rock, country, soul and funk inspirations of the Motown's repertoire, he will start, little by little, to aggregate these references in a unique artistic identity. This period, covered by six albums ${ }^{3}$, was characterized by a ferment of ideas and composition initiatives, but also by vocal initiatives. If, with the eponymous album The Jacksons 4 in 1976, Michael Jackson devoted himself, from then on, to writing and composing, he already dared, in his first two songs ${ }^{5}$, a few idiomatic vocal phrases that are less polished and orientated towards a rythmicity and a bruitism which will indeed soon form his own identity. On the album Goin' Places $^{6}$ in 1977, the singer integrated his first interjections, the future symbolic elements of his vocal style.

When he met Quincy Jones on the shooting of the movie The $\mathrm{Wiz}^{7}$, the singer, now of age, clearly expressed his resolution to break up his image of a star-child. The artist proved in the last family albums that he could, beyond his scenic performance, write, compose, produce and arrange. He then wanted to replace his brothers and sisters with professional musicians and decides to oversee each step of production and to set himself as the final arbiter in all artistic and aesthetic decision.

"I don't want to be a copy of those who were there before me, I don't want to constantly repeat myself, I must always innovate". (Cachin, 2009 : 39)

Michael Jackson's precept is an echo, at this crucial moment of his career, to Glynne Jones' words:

"It is important for singers to develop a unique style [...] The singer must cultivate

those aspects of his singing which are unique to him ». (Martin, 1983: 98)

Michael Jackson will inscribe his vocal personality and his catalogue in a soaring dynamic which gave up the comfort of repeats for an evolution that is sometimes destabilizing for the audience.

We now propose to analyze the components of Michael Jackson's vocal demarcation. And we will see how this plural identity is fed by a network of multi-aesthetical references with as a common point the interest shown by the singer-composer to textures and tone colors. 


\section{Vocal profile: technical and aesthetical elements}

11 We will now evoke Michael Jackson's voice according to the four main criteria of analysis mentioned by Allan F. Moore: tessitura and ambitus, tonal sense, vocal rythmicity and "resonance degree", and we will endeavor to show that the vocal work performed by the singer did not alter his quest of authenticity. On the contrary, we will complete these criteria by showing how this work brought about an increased malleability which was propitious to the plural references characterizing his timbre panel in a fundamental way.

12 Michael Jackson's voice, made of multiple expressions (melodies, buccal sounds, guttural sounds and vocalized noises at every level of his ambitus) was regularly worked and taken care of. Wanting to optimize his vocal instrument in all circumstances, Michael Jackson took up, from 1979, the advice of a vocal coach, Seth Riggs $^{8}$, who trained him all along his career, in a tailored way, daily, and even outside recording periods or shows.

\section{Tessitura and ambitus}

When Seth Riggs met Michael Jackson, the latter already owned a very broad ambitus. Quincy Jones, the artist's producer and arranger, wanted at that time to reduce by a minor third the tone of some songs of the album "Off the wall" so as to give the singer's voice more ease, suppleness and a timbre richer at the register's extremities. So Seth Riggs worked to further broaden the singer's ambitus and made him gain another fourth. Over daily sessions, his method of work and the exercises he required him to carry out had a view to (and this is an essential element of Seth Riggs's Speech Level Singing) gaining and retaining a vocal homogeneity on all his tessitura - Michael Jackson's one ranged from $\mathrm{E}^{1}$ to $\mathrm{G}^{4}$ without resorting to head voice or falsetto erasing the color interruptions and sensations of going from one register to the other. Cultivating, all along his career, the melodic, clear and expressive vocality of a tenor but also of a baritone, Michael Jackson even started working on the French lyric repertoire, although this work has remained unedited for strategic commercial reasons ${ }^{9}$.

14 Apart from this work on ambitus and equality between registers, the goals fixed by Seth Riggs were acquiring and maintaining vibrating tones by means of a constant harmonic balance and a relaxation vibrato allowing the artist to sing without being tired. Many exercises had also a view to managing the breathing, which was essential for the dancer.

We have to underline that the choice of Seth Riggs as a vocal coach clearly fell within Michael Jackson's quest of authenticity, since his method of work, although generically called Speech Level Singing, allows him to tailor and respect his pupils' vocal specificities.

\section{Resonance}

15 So with his vocal technique, Michael Jackson covered the resonance stratums evoked by Allan F. Moore linked to the voice's physical localization: head voice, nasal voice or chest voice. By erasing the changes of register, he allowed a unicity of transversal vocal 
emission that was contrary to the association that was generally admitted for pop music singers in terms of timbre inequality.

16 If the voice's nasal position is seldom taken into account in Michael Jackson's habits, the head voice is far more used although very often imperceptible thanks to a homogeneous management during the change of register. This head voice, confined to a very high-pitched tessitura no more goes with a loss of clarity and vocal strength than the extremely low-pitched chest voice of a song such as " 2000 watts ${ }^{10 "}$. It is worth highlighting that Michael Jackson's use of a de-toned head voice is due, in the few existing cases, to environmental or emotional reasons and not to a technical flaw - part of the work with Seth Riggs being focused on the vocal enrichment of vowels and their purified and distinct enunciation, even in the far ends of the tessitura ${ }^{11}$.

\section{Tonal sense and vocal rythmicity}

17 The other elements of analysis mentioned by Allan F. Moore: tonal sense and rhythm management are, in Michael Jackson's case, influent artifacts in the vocal restitution and the work in voice recording.

The tonal sense encompasses precision and accuracy and thus a voice's capability to place itself in a harmonic and polyphonic context. If Bruce Swedien's phrase: "Michael was able to hear a sound around the corner ${ }^{12}$ " conjures up an acute musical ear, the consequences of this image are translated in practical terms into the vocalized broadcasting of his compositions (including his melodic and harmonic components as well as a vocalized simulation of the expected instrumental timbre) via the producer or arranger whose task it is to record them, or if applicable, to each musician, without the intermediary of a prior recording. But this tonal sense also translated into developing and recording abundant vocal harmonies ${ }^{13}$, which allowed the sound engineer to create a specific technique ${ }^{14}$ precisely playing on tonality, technique he never used in works others than his work with Michael Jackson.

As for the singer's vocal rythmicity, this feature is not insignificant since, as we said before, it started developing as early as childhood in contact with the Motown repertoire, and led to a rhythmic potential that was from then on voluntarily exploited and highlighted since the album "Off the wall $1{ }^{15}$ " by the composer Rod Temperton ${ }^{16}$, who indeed explained that he voluntarily used his capabilities by giving him changing and rhythmic melodies such as those of the couplets from "Off the wall", or vocal up-tempo leads with a sharp delivery whose most striking example is "Working day and night". This management of rhythm and offbeat is a permanent feature that we will find again in a later repertoire, with, among others, the couplets from a title like "Jam" ${ }^{17 "}$.

\section{A vocal personality anchored in pluralism: from melodicity to bruitism}

19 Since ever passionate about sound, timbre, be them instrumental, vocal or concrete, Michael Jackson developed his experience by growing up in recording studios. The sound experiments he was interested and took part in went through creating complex textures that were then original ${ }^{18}$, often directly linked to concreteness and bruitism. Staked in the diversity of instrumental, electronic and concrete timbres, used or created, this interest was from the origin naturally exploited by his own instrument, 
his voice. And using "sleeker" influences such as funk, rock or rap, Michael Jackson implemented more original vocal expressions, which were complementary to his polished and well maintained vocal practice.

From the point of view of timbre and melody, he thus developed a vocality close to what Jean-Claude Eloy calls the dirty sound (Eloy, $22^{\text {nd }}$ June 1999), using raucous and saturated vocal textures, or keeping to unusual low notes, and he also gave their own musical status to shouting and interjections, which are consigned to vocal commentaries in funk or rock. By combining these timbre aspects to rhythmic parameters, he continued the work started by the Afro-American trends such as jazz and funk, making his voice a real percussion instrument that often uses the words' sonority as a priority (though without neglecting their sense), or that is totally moving away from them to plunge into a vocal and buccal bruitism, which finds its best expression in beatboxing ${ }^{19}$. Thus, in a song like "Shout ${ }^{20 "}$ or in the rap of "Can't let her get away ${ }^{21 "}$ ", he drastically modified his vocal texture to make it a raucous flow away from any measurable height but playing with vocal impulsions and words' rythmicity until reducing the text to its purest sound frame, away from sense. The singer's voice oscillates then between a physical and concrete verve and a synthetic unreality (without using any artificial effect though), between a human voice bearing a text and an instrumentalist mutation of this voice. Michael Jackson pushed these practices further; he displayed them and in a way imposed them, to the point that they became the symbols of his vocal personality. An interjection or some vocal noises at the start of a song like the famous t-k-tch-tch or hee! hee! which open respectively (and among others) "Billie Jean ${ }^{22}$ " or "The way you make me feel23", quickly became an instant mean of identification for the audience, in the way of initials or a vocal signature.

By combining in his melodic expressions some multi-aesthetic and poly-expressive principles which combine unpolished, aggressive or strange timbres, shouting and rythmicity, Michael Jackson created a vocal personality that is his own and is at once recognizable by a large audience. He admittedly levelled at the surface some clearly anti-establishment expressions by melting them in his music and vocality's eclecticism, but he also contributed, in doing so, to make these expressions popular and to galvanize them, in a more massive acceptation conveyed by the pop inspiration. And even among the anti-establishment inspirations, he, with this personality, dared and allowed to conciliate ${ }^{24}$ (Thonon, 1998: 95) rock and rap by often combining them in the same song ${ }^{25}$. It is then by uniting and overhanging these popular aesthetics that Michael Jackson managed to create an authentic personality and be the mirror of the greater number.

We will now explain how Bruce Swedien, bearer of a philosophy of the sound that continues Michael Jackson's quest of authenticity and unicity, was the technical architect of what he established as the real vocal double of the artist, and we will evoke the sound engineer's conceptual and technical approaches, traditional or innovative, but always converging towards the same goal: keeping and reproducing the distinctive identity and harshness of Michael Jackson's voice. 


\section{Translation of a sound into image and recorded restitution of Michael Jackson's vocal personality}

\section{A key character. Bruce Swedien}

«The best engineers draw their reservoir of knowledge and experience to manage the interface between music and machine, art and technology, with a sensitivity to musical expression guiding their own technical "performance"». (Zak III, $2001: 168$ )

Sonorist and architect of Michael Jackson's voice from Off the wall in 1979 to Invincible in $2001^{26}$, Bruce Swedien, nicknamed "the philosopher of sound" by his peers, is the one who dramatically changed the status of sound engineer from technician to co-artist. His career sweeps all the evolutions of studio work that have lined the twentieth century: indeed, his career started in the 1950s, when studio work was only in its infancy, with recording orchestras and classical choirs in Minneapolis, but also with experimenting his techniques with great names such as Count Basie, Duke Ellington, Dizzy Gillespie, Lionel Hampton, Oscar Peterson, Sarah Vaughan; he saw the multitrack evolution since the acquisition of his first four-track in 1959, and he saw the digital revolution. And yet, this colleague and admirer of Bill Putnam - who was a pioneer in technologies still used today like reverberation and echo - kept, all along his career, this motto: "Music first", relegating to the background the use of technology that he often considers too systematic and artificial ${ }^{27}$ in popular music.

Just as mastering does not constitute, for Bruce Swedien, an ultimate step where one saves music, he claims not to be an adept of corrective technology (and this even in terms of equalization, which he prefers to manage directly in the musician's position in front of the mike, instrument by instrument, even in the case of an orchestra), and clearly prefers a creative function.

It is worth noting that the care shown to the details of the sound field orchestrated by Bruce Swedien was made possible by a choice that was then avant-garde, and that remained his exclusivity for a long time: the use of Monster Cables (Swedien, 2009a : 110-111) created by his friend Noel Lee ${ }^{28}$. Those were the first high-fidelity cables to compensate, once and for all, for the variable degrees of audio performance achieved by the standard zip-cords, cables that were up to then used indistinctly for sound, domestic electricity and lamps. It is thanks to the use of connectors in 24-carat gold that these high-performance audio-phonic cables were created; they were going to considerably improve for Bruce Swedien, from 1987 and the album Bad ${ }^{29}$, the sharpness of the perception of the elements staged in the sound field, and in particular the approach of Michael Jackson's voice, whose forms of expression, lyrical or pointillist, scatter the song's different stratums.

\section{A common quest}

«Certain producers (...) choose their engineers very carefully, because the producers know that those engineers are going to bring certain aspects to the record». (Zak III, 2001: 170)

If the producer Quincy Jones was the vector of the encounter between Bruce Swedien and Michael Jackson in 1979, it was however Michael Jackson himself, as a producer but above all as an artist, who will extend and cement his collaboration with the sound engineer for many years, well after the break-up with his initiator. 
Supplying a work of precision and taking special care of every slightest detail are two professional features that brought the two men together. But beyond that, it is around the quest of a certain authenticity that their collaboration was sealed, implemented by the singer's vocal corporality and the engineer's most natural technical approach possible.

Authenticity, for Bruce Swedien, starts with respecting the original musical substance of a song. Indeed, he explains that if, most of the time, finalized songs are, following countless remodeling in studios, generally very different to their original concept to end up dissolved in the fashionable sound landscape, his reasoning, particularly with Michael Jackson, was exactly meant to be the contrary. Anxious not to move from the original concept that is always precisely defined by the artist (or often even recorded vocally and very thoroughly ${ }^{30}$, which allowed him to regularly go back to it), mindful of the musical spirit inherent in each song, he always tried to restitute with fidelity the singer's vocal intentions, in a high fidelity that has - in its own words - nothing impersonal or sterile.

We will now see how, sharing with Michael Jackson this concern for a precise sound restitution, Bruce Swedien opted for technical choices that always put the emphasis on the proximity with the mike, the natural spaces or effects, and a three-dimension management of the sound space in which each form of the singer's vocal expression finds its place.

\section{The mike as a vector of authenticity}

The first tool to convey the components of Michael Jackson's vocal personality is the microphone. It will be used as the extension of the singer's body and not as a tool of artificial remodeling. Indeed, the apparition of mikes and technological tools allowed, in the sacred den of the studios, to rework the human voice as well as the instrumental timbres. It resulted in experiments which contributed to make of these tools and other computers the new bellies where everything was created, shaped, artificially redesigned. These techniques, applied to pop music, are the very foundations of the synthetic inspiration, but they also spread to all currents. Yet, unfortunately, they were too often the ones which were, due to their emphatic use, made to simplify or correct, at the origin of the notion of easy effect that symbolizes, and often shades, the image of pop music.

Thus, for a while, the microphonisation of the voice provoked the indignation of some theoreticians, such as Raoul Husson (1962: 75), for whom singing with a mike could only alter the voice's own timbre and lead to negating the individual vocal culture. On the contrary, composers like John Cage saw in the mike the means to reproduce a more natural voice than the technique of organic amplification of the Bel Canto. Indeed, and as regards dematerialization, the microphone allowed, in Michael Jackson's case, to bring the ear closer to the body by contributing to reveal his gesture in the phonation. This is really about the instrumental use mentioned by Michael Chanan in his book Repeated takes (Chanan, 1995), which inspired and initiated new vocal practices, among which close miking, put to practice by Bruce Swedien.

The notion of vocal personality as used by Bruce Swedien to talk about Michael Jackson's voice is interestingly similar to the idea of "acoustic photography" ${ }^{31}$ " expressed by Sophie Herr (2009: 108) which is indeed defined, from the start and 
beyond the simple outline of a dematerialized body, by the recording of a style, a way of being, an authenticity of "the being-in-life" that a breathing shows before anything else. With this shared conception, Bruce Swedien gives us more to listen than the singer's voice. He makes us prick up our ears to the sound body, full-fledged member of the visible body, which it outstrips and overtakes:

«Close microphone placement brings the sound forward, suggesting, as one writer says of Bing Crosby's crooning, "an intimate, personal relationship with fans"». (Chanan, $1995: 128$ )

31 A new phenomenon of intimacy, underlined by Simon Frith (Frith et al., 2001: 98), then springs up between the audience and the artist, who participates in the barthesian voice grain and who, thanks to the mike, lets the audience suddenly hear a voice tone that was until then kept for intimate conversations. And this approach, relayed by Bruce Swedien and Michael Jackson, also participated in this intensification of the vocal supremacy, started in the late 1940s, and which ended up by superseding the compositional touch in the aestheticism of popular songs.

More than amplify and bring the singer's voice, the mike indeed allowed Bruce Swedien to do a close-up on where the voice is born, the body, making in his own way from the barthesian vocal grain this "erotic mix of timbre and language" (Barthes, 1973: 88-89) in close relation to the cinematographic sound take by which the semiologist defined his thoughts.

"The cinema only needs to take the voice sound from very close and let hear in their materiality, their sensuality, the breathing, the rocky sound, the lips' flesh, a whole presence of the human muzzle..."(Barthes, 1973: 88-89)

«What I listen for is transparency, where the idea moves from its inception to the listener with the least amount of forces impeding it». (Zak III, 2001: 169)

To implement this approach and reproduce with fidelity the corporeal vocality of this vocal body, Bruce Swedien's technical choices resulted in processes of sound capture that were the most natural possible (in the non-technological meaning of the word) which met his friend George Massenburg's ${ }^{32}$ concern for transparency. Operated by the necessarily invisible hand of the engineer, this capture had to comprehend a whole sonorous and bruitist body, generated by the body theatre of its source, always moving and interacting somehow with the voice's rhythmic impulsions. His irrepressible dance movements during recording sessions and the percussive and emotional use of the singer's body and mouth (breathing, sonorous inspirations, vocal hiccups, distorted or exaggerated pronunciation of words, finger snapping or feet stamping) could only be, as reflects of his personality and his ethnic and social origins, necessary stakeholders of his vocal field. And this does not take into consideration the direct and traditional research of effects, highlighted by Matt Forger ${ }^{33}$, another of the artist's sound engineers, and which translates into deliberated attitudes towards the mike (moves or occasional distancing) as well as a parsimonious use, reduced to minute exceptions, of the compression tool on the singer's voice (use that is otherwise widespread and almost inevitable for most pop artists), and this so as not to write off or alter this assumed bruitist dimension.

It is in the same spirit that Bruce Swedien chose to record the singer's voice analogically, preferring to avoid the artifacts that are added during the digital process and distort, even minutely, reality. This marked preference for an analogical and mono-phonical image of the source point allowed him to preserve the richness of the sound prism and a natural profile. The main point, for Bruce Swedien, really consisted 
in recording and mixing the singer's voice so that the information coming back from the speakers keep and respect as much as possible the sound field's value.

Before addressing in detail the technologies used, on top of which we will put the choice of mikes, we have to study a paramount tool whose use was made necessary by the importance of retaining the components inherent in this vocal image: plywood.

\section{Function and impact of plywood in the singer's vocal image}

«One aspect of an engineer's task is to afford performers a sense of well-being in the studio » (Zak III, $2001: 166)$

Michael Jackson was as much a singer as a dancer. The practice of these two arts participated in a one and only nature, so much so as the fact of singing irrepressibly generated corporeal movements in the artist. Forbidding the interpret to dance or eliminating the sound and vocal impacts his movements had by means of compression would have been close to what Bruce Swedien calls a totally distorted surgery approach.

So as to let Michael Jackson freely use his movements and keep, without having to artificially treat them, the fair necessary part of sounds and corporeal percussions being integral part of his vocal personality, Bruce Swedien ordered, in 1979, a plywood stage that became the recording center of the singer-dancer. This platform was thought and made accordingly: created by the studio's carpenters, eight feet wide and ten inches over the ground, it was doubly reinforced. Its surface was kept unvarnished and unpainted so as to allow a porosity of the material and thus some phonic absorption. It also made it possible to avoid that a direct contact with the ground bring about a resonance that would spread and create interferences.

\section{Mikes: choices, position and technical features}

"[The voice grain] implies a certain erotic connection between the voice and the listener". (Barthes, 1981 : 200)

The eroticism Roland Barthes brings to light here is closely linked to the singer's body tangibility, his own "body contributions to the piece“, according to Paul Valery's ${ }^{34}$ own phrase, underlined by a physical proximity to the mike which, we will see, was precisely used to amplify the barthesian vocal grain found in Michael Jackson. If choosing a type of mike was carefully done for this restitution, we will see that it was indeed the same for the position of the singer.

Thus, for the main melodic lines of songs, or vocal leads, close miking was Bruce Swedien's favorite technique: by placing the singer very near the mike, he could naturally erase most of the echo and surrounding noises, keeping the voice's direct sound. Contrary to studios' common practices, he did not use any windscreen, so that he did not lose the small corporeal noises of the singer, then he adapted, if necessary, the predelay, according to the piece speed, using the emblematic EMT 250 Electronic Reverberator Unit, considered until today by professionals as the best reverberation tool and the reference from which all the current digital reverberations have been defined.

By placing in this way the mike near the mouth and by recording the slightest buccal, breathing and corporeal noises made by Michael Jackson, yet without inducing any expressive surcharge, Bruce Swedien actually revealed and staged this proximity, this vocal intimacy that Michael Chanan was mentioning above, and he brought to light, in 
a way, part of this "worrying strangeness ${ }^{35}$ " which fascinated and sometimes disturbed the audience.

Concerning the choice of mikes, if he owns one hundred and five of them, Bruce Swedien only privileged two, taking into consideration Michael Jackson's vocal parameters. The mikes, unequally used, are not the fruits of the latest technologies but result from reliable products that he judges un-superseded ${ }^{36}$. But, since, for the engineer, it is not about producing a music that is scientifically state-of-the-art and that "would not communicate anything" (according to his own words), he makes uncompromising choices, without being fundamentally conservative, but guided by his experience of technological evolutions.

41 This is how Bruce Swedien's favorite mike, the very one he will use to record all Michael Jackson's vocal parts (except for a sole song we will later mention), is the dynamic Shure SM-7 mike. Bought in 1977 from the Westlake Audio in Hollywood, his Shure SM-7 was the first one to be used in great-scope musical projects. The sound engineer explains his choice in relation to Michael Jackson's prerogatives and particularly to the quality of the sound that it reproduces, transparent, accurate, non artificial in the high-pitched sounds and offering much presence. Well suited to dynamic voices, the Shure SM-7 does not flay the sibilant consonants the singer frequently uses. These ones appear smoothed, with a slightly piping sonority, without losing body. On the contrary, the mike slightly enriches the texture. The Shure SM-7 indeed requires, in accordance with Bruce Swedien's practices with Michael Jackson, to be used very near the source of sound emission, and gives a great warmth that flatters the voice, as much as an acute restitution of the vocal dynamic. By recording Michael Jackson with this mike, Bruce Swedien obtained a very neat and acute sound image. Being, moreover, hardly reactive to the surrounding sounds, the Shure SM-7 was a first "natural" filter to the singer's corporeal sounds, and warranties, with the plywood, to only keep the necessary part. This is the reason why Bruce Swedien did not assign any more windscreens, which would have run the risk to erase the breathing sounds and the explosives sonorous emissions that were indeed intended.

The only song that was not recorded with the Shure SM-7 was "Earth Song" on the album HIStory Past, Present and Future ${ }^{37}$ in 1995, song bearing a half-apocalyptic, halfprophetic message in which Bruce Swedien chose to underline and timbre the singer's voice with a mike offering a warm sound, capturing a larger sound spectrum: the Neumann M-49. This electrostatic mike was created in 1949, commercialized in 1950, and bought by Bruce Swedien soon after his very first mike (that was the Telefunken $\mathrm{U}-47)$. For the engineer, it is an excellent mike for voice recording, even though its specificities allow it to be used for many other applications ${ }^{38}$. The Neumann M-49 is multi-directional and totally adjustable, and allows an omni-directional use, which is interesting for capturing vocal backgrounds for example. The rich and round tone it reproduces gives the harshest sounds some pleasant and warm colors. And it is the incantatory structure of this song's chorus, made of high-pitched singing exercise, and the final ad libitum treated as shouting, that made it necessary to incorporate additional warmth to the vocal image, and thus dictated to Bruce Swedien the choice of this mike.

As we saw, the voice became significantly important as an identity in the popular aestheticisms, even overriding the role of the composer, to the extent that it became a major milestone in the arrangements, so much so as often dethroning the instruments. 
«Voices became central to the group's musical arrangements - vocal harmonies and back-up chorus sounds had to do the job of the strings and echoes and studio tricks of the teen pop records». (Martin, $1983: 32$ ) when beyond the vocal leads which form the emerging part carried and expressed by his voice, his vocal personality fans out in the different musical stratums of the songs, from the melody harmonization to the almost-instrumental implementation of melodic, rhythmic or buccal and unvoiced elements of the accompaniment. All these elements were suitably recorded so as to find a position in a sound space that Bruce Swedien does not only want to be stereophonic but also tri-dimensional.

\section{A multi-expressive vocal personality in the sound space}

\section{Bruce Swedien's tri-dimensional sound space}

The sound space and the three dimensions play a large part in Michael Jackson's recorded vocal aestheticism. The sound space as it is explored by Bruce Swedien can be compared to Roberto Casati and Jerome Dokic's (1994: 102) description of a "space accessible to the corporeal movement, and in which (that is to say, in some parts of which) sounds are produced, that can be located by a listener". It is in this seemingly empty material surrounding the body that Michael Jackson's vocal personality and the sonorous events it is formed of were organized by the engineer to create a sensory substance and a sound image in the three-dimension space. One supports and adds value to the other, as the décor and dramatization stage the character, here a real organic vocality.

If, for Bruce Swedien, the stereophonic space is deeply tri-dimensional, it is because he does not consider it as a mere effect of lateralization, but as a full occupation of the acoustic panorama by sonorous characters whose respective vital spaces do not muffle each other. In the manner of Sophie Herr for whom the "acoustic photography" (Herr, 2009: 74) breaks the mirror of a thought according to the eye and thus could not be the reflection of anything, Bruce Swedien does not consider the sound image as the reproduction of any realist space positioning of the sound and takes this conception after the 1950s, conception that emerged following the success of an emblematic song by Les Paul and Marie Ford "How high the moon" ${ }^{39}$ ". This song, indeed, long before multi-track recorders appeared, was built around an overlapping of pre-recorded vocal and harmonic lines called overdubbing, on which, during television shows promoting this novelty ${ }^{40}$, the main melody was the only voice that was put live, in reality. The awareness linked to this song was, for Bruce Swedien, to change the notion of sound exactness, this quest of purity symbolized by high-fidelity, to a notion of comprehensive sound image, endowed with a depth of field and an acoustic relief whose limits were from then on fixed by the creator-composer-engineer's imagination. And the idea of transparency, mentioned above, occurs precisely when the handling of the sound reality becomes, for the listener, a reality in itself.

To place Michael Jackson's voice, with all its aesthetic and organic components, in a sound frame that underlines it or wraps it without using any artificial effects at the opposite of the intended authenticity, Bruce Swedien strove to create real and adjustable acoustic spaces in the studio. His choice was, as for the Monster Cables, stateof-the-art material with the adoption, from the album Bad in 1987, of gobos from the 
newest generation called Tubetraps, thought and created by his friend Arthur M. Noxon from Acoustic Sciences ${ }^{41}$. These Tubetraps are cylinders with designed shapes, mounted on a base and equipped with special acoustic coatings allowing to modulate spaces endowed with sonorous features that can be, despite outside variables, highly predictable. The Tubetraps, variation of the Quick Sound Fields, are quick in terms of installation as well as of reactivity, since they recreate a realist sound field without unwelcome reflection or floating echo. Some cylinders are hollow and covered with a densely woven fiberglass. It results a great rate of pressure between the highly resistant surface and the hollow inside, pressure differential that contributes to maximize the acoustic speed. The innovative particularity of these Tubetraps was that, at the same time, the whole surface of the cylinder would absorb the spectrum of lowpitched sounds, whereas a half of it also let diffuse the high-pitched spectrum with brightness and a controlled clarity. This hybrid acoustic is made possible by suspending a thin but heavy sheet of perforated soft plastic covering half the front face of the cylinder. The hybrid features of the plastic sheet allow absorbing the low-pitched frequencies and reflecting the high-pitched ones. These Tubetraps were then placed around the plywood on which Michael Jackson was singing, and disposed on a circle with a diameter of three meters. However, it is worth noting that the singer, familiarized with the studios' tools and their technical constraints, would adjust himself their position according to the vocal reflections he wanted to obtain.

It is thus within these controlled acoustic spaces that the singer was recorded, and, coupled with the techniques of voice take we will now mention, this staging plays on proximity and physicality while underlining the characteristic vocal aspects called by the mind and the musical energy peculiar to each song.

\section{The vocal leads: an underlined presence}

As we saw, Michael Jackson's vocal leads were monophonically and analogically recorded, the singer being placed very near the microphone Shure SM-7 so as not to lose all the bruitist and corporeal particles linked to his sound identity. But Michael Jackson also created himself his vocal harmonies, overlaying, with an accuracy Bruce Swedien insisted on, his vibrato on each line. In this phase of recording, the singer first doubled the same track while keeping the same proximity to the mike, then, at the third take, he would take a step back and record again the same melodic line. Bruce Swedien would then turn the sound level of this third take up to the same degree as the first two. This process resulted in an increase in the proportion of early reflections and created a first reinforcement of the sound richness.

49 A fourth take allowed him to record from an even further distance, but this time in stereophony, by using two mikes, set up in an X-Y pair, or "Blumlein Pair"2". This method was conceived by Alan Dower Blumlein ${ }^{43}$ : it is the best known stereophonic technique and the one Bruce Swedien favored. Very simple, it consists in placing two bidirectional microphones, one opposite the other so that the capsules converge as much as possible while keeping an angle of 90 degrees between them. The result of this take is added to the previous ones.

It is this addition of early reflections that is at the origin of the depth of field present in the different blocks of vocal harmonies in a number of Michael Jackson's songs' choruses. The title "Rock with you ${ }^{44 "}$ of the album Off the Wall was the first one to display this process, and creates an acoustic effect that was innovative at that time, the 
outcome being, at the other side of his career, the large vocal unfolding of the song "Butterflies ${ }^{45}$ " in 2001. Let's note that the same process was applied to Andrae Crouch's choir in the song "The man in the mirror ${ }^{46 "}$ " of the album Bad, and creates there a sound density that amplifies the choir and makes it exist in the whole field. It is worth adding that in this particular case, and since a great reverberation was added to this vocal part, Bruce Swedien precisely made sure to plan enough initial delay for this reverberation not to cover the early reflections.

\section{Vocal harmonies: impact of stereophony and depth of field}

51 The poly-expressive nature of Michael Jackson's vocal personality was thereby exploited, underlined and emphasized through recording techniques. We saw how the singer's vocal harmonies were not only stratified but also put into perspective in the acoustic field and what impact the stereophonic sound takes play in this sound staging: applied to the vocal backgrounds, they play on the depth of field; applied to the choir, they give it a tangible presence. Finally, used for the orchestra, as in the song "Childhood ${ }^{47}$ ", the stereophony exploited by Bruce Swedien weaves a network of spatial relationships between the instrumental ensemble and the listener and maintains the latter in a real perspective of concert audience. Bruce Swedien has also been raising an interest in stereophony since the 1950s, when many directors of recording companies did not anticipate the upcoming revolution and did not want to invest in this field. Whereas some of them bet that, not more than a "shower with two heads" ${ }^{48}$ ", stereophony had not any interest, Bruce Swedien, like his model and friend Bill Putnam, had, on the contrary, installed a separated control station hidden at the back of the studio to make some experiments in stereo, which allowed him later to be a step ahead in this field. $\mathrm{He}$ had indeed grasped from the beginning its interest in terms of depth of sound space and expressive impact.

Let's note that Bruce Swedien's recordings by stereo pairs, applied to vocal backgrounds but most of all systematically applied to the instruments, were for a long time a unique method of work, called Acusonic Recording Process by Quincy Jones, and had a whole generation of engineers think about the notion of stereophony again. Suspected at a certain time to be a new technological tool kept secret, the Acusonic Recording Process (combination of accurate, referring to the accuracy of the sound image of real stereophony, and sonic, referring to the sound one tries to personalize) actually designated a process designed by Bruce Swedien, aiming to combine several multitrack recorders, so as to multiply the stereophonic pairs ${ }^{49}$. He used up to ninety-six of them for the song "Places you find love $\mathrm{e}^{50}$ " by Quincy Jones. Michael Jackson's music required on average sixty-six audio tracks (that is three linked appliances of twentyfour tracks, given that a track of each appliance was used to synchronize the time code SMPTE and that another one was kept empty to avoid generating any interference) (Swedien, 2009a: 109-110). The fact to have on disposal as many tracks as necessary ${ }^{51}$ indeed allowed Bruce Swedien to multiply the stereo images in the sound fields of Michael Jackson's music and this process contributed more than any other to create a qualitative demarcation and a new sound identity.

But the singer's vocal harmonization also led to other specific recording processes. Indeed, very early in his collaboration with Michael Jackson, Bruce Swedien grabbed the opportunity to create, from the singer's voice, a sound perspective using the width and depth of the space. He explains that the artist's vocal abilities, coupled with his 
interest and his liking for sound experiments, made him a great laboratory of experiments. Moreover, Quincy Jones and Michael Jackson being always enthusiastic about Bruce Swedien's creative sense, the latter was always entirely free to bring his own personality to music. It is in this favorable context that, supporter of natural techniques, Bruce Swedien had Michael Jackson make, singing live, effects on the dubbing of his main voice: to give even more relief to the sound texture of these vocal blocks, the sound engineer would very slightly slow down the recording of the main voice during the dubbing (three or four percents), and thus, at the same time, very slightly lower its tone. Michael Jackson would record the dubbing keeping into account this new micro-tone. Then, Bruce Swedien would combine the two voices, with their near imperceptible gap in frequency, by mixing the sound level of the double track slightly below that of the vocal lead. This technique, which needs a good relative sense of tone and a great vocal precision, as Bruce Swedien, for which this experiment remained unique, underlines, allowed bringing support to the voice by enriching its sound spectrum in a natural and real way, without resorting to any artificial reprocessing.

\section{Conclusion}

So, if Michael Jackson did not stop developing, improving or renewing his vocal and musical personality, he particularly took care, in parallel, to convey it with fidelity. He was committed to developing an innovative and independent aestheticism, symptomatic of a driving force consisting in always going forward instead of enjoying the safe comfort of the previous success. By coupling his vocal abilities with daily work on his tessitura and vocal timbre, he managed to create an original sound personality, summoning and restoring the entire corporeal sphere in his voice.

In the manner of contemporary creation which has a taste of this barthesian voice grain and which lends an ear to the body, Michael Jackson's approach focused on reinstating a tangible physicality in the vocal field. Using his voice as a music instrument in its own right, the singer laid it on his songs' every musical stratum including melody, harmonies, voiced cells or rhythmic projections of the melodic-rhythmic framework, low-pitched vocalized lines. He did not confine it to conveying an expression of intellect and emotion, but established it as the sound media of a whole body organically interacting in the vocal image and whose smallest particles of presence, maintained in the final mix spectrum, play a major part in restoring this authenticity. The techniques used to that effect by the sound engineer Bruce Swedien aimed to, by studio strategies avoiding artificial reprocessing, structure each vocal intervention, be it linear or pointillist among an acoustic space that is deeply three-dimensional, without losing any of the link of auditory intimacy woven between the interpreter, through his sound double, and the listener.

Michael Jackson established his vocal personality through a very large popular musical aestheticism, not stigmatized, by developing an expressive plurality looking into the multiplicity of aesthetical, ethnical or social references of the pop cultural syncretism. Admittedly, the work conditions offered by the artist, in terms of budget and time, will remain for a long time an exception accounting for the long studio strategies often implemented - from parsimonious recording of orchestras to the creation of unprecedented sound entities combining concrete elements, electronic and 
instrumental timbres - as well as the hard-line character of the approach. Indeed, Michael Jackson self-funded a great part of his work in studio, trying at the same time to keep certain autonomy; he also equipped the studios with state-of-the-art facilities and allocated much extended work deadlines, sometimes facing the contracts requirements; in short, he managed to gather paramount factors which all and each of them contributed to achieve a substantive work.

\section{BIBLIOGRAPHY}

But, beyond this, the sound and artistic ethics shared by Michael Jackson and Bruce Swedien will probably remain, upstream from all other technical element, the key to what should be called a true musical demarcation in international popular music of the twentieth century.

BARTHES Roland (1981), Le grain de la voix,Entretiens 1962-1980, Paris, Seuil

BARTHES Roland (1973), Le plaisir du texte, Paris, Seuil

CACHIN Olivier (dir) (2009), Michael Jackson, le phoenix pop, Lausanne, Consart

CADMAN Chris \& HALSTEAD craig (2007), Michael Jackson for the record, Bedfordshire, Authors on line

CADMAN Chris \& HALSTEAD Craig (2002), Michael Jackson the Early Years, Hertford, Authors on line

CADMAN Chris \& HALSTEAD Craig (2003), Michael Jackson the Solo Years, Hertford, Authors on line

CASATI Roberto \& DOKIC Jérôme (1994), La philosophie du son, Nîmes, Jacqueline Chambon, coll.

«Rayon Philo»

CHANAN Michael (1995), Repeated takes. A short history of recording and its effects on music, London, New York, Verso

CUNNINGHAM Mark (1996), Good Vibrations, A history of Record Production, Tampa, Sanctuary

Publishing Ltd

FRITH Simon, STRAW Will \& STREET John (2001), The Cambridge Companion to Pop and Rock, Cambridge, New York \& Melbourne, Cambridge University Press

HERR Sophie (2009), Geste de la voix et théâtre du corps. Corps et expérimentations vocales à la croisée des pratiques

du XXe siècle à nos jours, Paris, L'Harmattan, coll. L'art en bref

HUsson Raoul (1962), Le chant, Paris, P.U.F.

JACKSON Michael (1988), Moonwalk, Paris, Michel Lafon

JONES Quincy (2003), Quincy, Paris, Robert Laffont

LARNAUDIE Suzanne (1988), Paul Valéry: réflexions sur le corps, Boulogne, Association pour la diffusion de la recherche littéraire.LANGER Daniela (dir.) (21-25 juin 1999), Les chemins de la musique: «Entre son et bruit, la musique», France Culture

MARTIN George (dir.) (1983), Making music. The guide to writing, performing \& recording, London, Pan Books Ldt 
MERCIER Denis (2007), Le livre des Technique du son, Tomes 1,2,3, Paris, Dunod

MOORE Allan F. (2/2001), Rock: The Primary Text - Developing a Musicology of Rock, : "Elements of an analytic musicology: the voice", Ashgate, Aldershot \& Burlington

SMITH Suzanne E. (1999), Dancing in the Street: Motown and the Cultural politics of Detroit, Cambridge, Harvard University Press

SWEDIEN Bruce (2009), In the studio with Michael Jackson, New York, Hal LeonardswEDIEN Bruce (2009) Make mine music, New York, Hal Leonard

THONON Marie (dir.) (1998), Le son et la voix, entretiens avec Michel Chion, Paris, L'Harmattan

The Official Michael Jackson Opus, (7 décembre 2009), éd. opus media group limited, ISBN-10: 1905794282 ISBN-13: 978-1905794287

ZAK III Albin J. (2001), The Poetics of Rock. Cutting tracks, making records, Los Angeles, University of California Press, Berkeley

DISCOGRAPHY

THE JACKSONS CHRONOLOGICAL DISCOGRAPHY

THE JACKSONS, The Jacksons, [disque 33 Tours, cassette, CD], prod.Gamble and Huff / Philadelphia International Records, label Epic, 1976.

1. Enjoy yourself (3:24) 2. Think happy (3:07) 3.Good times (4:57) 4. Keep on dancing (4:31) 5.Blues away (3:12) 6.Show you the way to go (5:30) 7. Living together (4:26) 8. Strength of one man (3:56) 9. Dreamer (3:05) 10. Style of life (3:19)

THE JACKSONS, Goin' Places, [disque 33 Tours, cassette, CD], prod.Gamble and Huff /

Philadelphia International Records, label Epic ASIN : B0012GNOLW, sortie 18 octobre 1977.

1.Music's takin' over (4:26) 2. Goin' places (4:30) 3.Different kind of lady (3:35) 4. Even though you're gone (4:31) 5. Jump for joy (4:42) 6. Heaven knows I love you girl (3:55) 7. Man of war (3:13) 8. Do what you wanna (3:31) 9. Find me a girl (4:34)

MICHAEL JACKSON CHRONOLOGICAL DISCOGRAPHY

JACKSON, Michael, off the Wall, (Special edition) [CD], prod. Inc, label Epic / Sony ASIN: B0025MOLTG, (1979) sortie 16 octobre 2001

1. Don't Stop 'til You Get Enough (6:04) 2. Rock With You (3:40) 3. Working Day And Night (5:04) 4 . Get On The Floor (4:57) 5. Off The Wall (4:06) 6. Girlfriend (3:04) 7. She's Out Of My Life (3:38) 8. I Can't Help It (4:29) 9. It's The Falling In Love (3:48) 10. Burn This Disco Out (3:48) 11. Voice-over Intro Quincy Jones Interview/Quincy Jones \#1 (0:37) 12. Voice-over Intro Don't stop 'til you get enough (original demo from 1978) Quincy Jones (0:13) 13. Don't stop 'til you get enough (original demo from 1978) Michael Jackson (4:48) 14. Quincy Jones Interview \#2 Quincy Jones (0:30) 15. Voice-over Workin' day and night (original demo from 1978) Quincy Jones 16. Workin' day and night (original demo from 19758) Michael Jackson (4:19) 17. Quincy Jones Interview \#3 Quincy Jones (0:48) 18. Voice-over Intro Rod Temperton Inteview/Rod Temperton (4:57) 19. Voice-over Intro Quincy Jones Interview \#4 Quincy Jones (1:32)Bas du formulaire

JACKSON, Michael, Thriller, [disque 33 Tours, cassette, CD], prod. Quincy Jones, Michael Jackson, label Epic / Sony EPC 504422 2, sortie 30 novembre 1982

1.Wanna Be Startin' Somethin' (6:02) 2. Baby Be Mine (4:20) 3. The Girl Is Mine (with Paul McCartney) (3:42) 4. Thriller (5:57) 5. Beat It (4:17) 6. Billie Jean (4:57) 7. Human Nature (4:05) 8. 
P.Y.T. (Pretty Young Thing) (3:58) 9. The Lady In My Life (4:57) 10. *Someone In The Dark (Bonus Réédition 2001) (4:48) 11. *Carousel (Bonus Réédition 2001) (2:01)

JACKSON, Michael, Bad, Special Edition [CD], prod. Quincy Jones, Michael Jackson, Label/Réf: Epic / Sony ASIN : B00005NUZO, (1987) sortie 15 octobre 2001.

1. Bad (4:07) 2. The Way You Make Me Feel (4:59) 3. Speed Demon (4:01) 4. Liberian Girl (3:54) 5. Just Good Friends (4:08) 6. Another Part Of Me (3:55) 7. Man In The Mirror (5:19) 8. I Just Can't Stop Loving You (4:25) 9. Dirty Diana (4:52) 10. Smooth Criminal (4:19) 11. Leave Me Alone (4:40) 12. Streetwalker (5:49) 13. Todo Mi Amor Eres Tu (4:04) 14. Fly Away (3:26)

JACKSON, Michael, Dangerous, [cassette, CD], prod. Teddy Riley, Michael Jackson, Label/Réf: Epic / Sony EPC 504424 2, sortie 21 novembre 1991.

1. Jam (5:39) 2. Why You Wanna Trip On Me (5:24) 3. In The Closet (6:32) 4. She Drives Me Wild (3:41) 5. Remember The Time (4:00) 6. Can't Let Her Get Away (5:01) 7. Heal The World (6:24) 8. Black Or White (4:16) 9. Who Is It (6:35) 10. Give In To Me (5:29) 11. Will You Be There (7:40) 12. Keep The Faith (5:58) 13. Gone Too Soon (3:22) 14. Dangerous (6:59)

JACKSON, Michael, HIStory, Past, Present and Future, [CD], prod. Michael Jackson, Label/Réf: Epic / Sony EPC 474709 2, sortie 16 juin 1995.

CD1

1. Billie Jean 4:54 2. The Way You Make Me Feel 4:57 3. Black or White 4:15 4. Rock with You 3:40 5. She's Out of My Life 3:38 6. Bad M.Jackson 4:07 7. I Just Can't Stop Loving You 4:12 8. Man in the Mirror 5:19 9. Thriller 5:57 10. Beat It 4:18 11. The Girl Is Mine (duo avec Paul McCartney) 3:41 12. Remember the Time 3:59 13. Don't Stop 'Til You Get Enough 6:05 14. Wanna Be Startin' Somethin' 6:04 15. Heal the World 6:24

$\mathrm{CD} 2$

1. Scream (4:38) 2. They Don't Care About Us (4:45) 3. Stranger In Moscow (5:45) 4. This Time Around (4:20) 5. Earth Song (6:45) 6. D.S. (4:50) 7. Money (4:40) 8. Come Together (5:25) 9. You Are Not Alone (5:45) 10. Childhood (4:28) 11. Tabloid Junkie (4:30) 12. 2 Bad (4:50) 13. HIStory (6:35) 14. Little Susie (6:15) 15. Smile (4:55)

JACKSON, Michael, Blood on the dancefloor, HIStory in the mix, [cassette, CD], prod. Michael Jackson, Label/Réf: Epic / Sony EPC 487500 2, sortie 21 avril 1997.

1. Blood on the Dance Floor (4:13) 2. Morphine (6:28) 3. Superfly Sister (6:27) 4. Ghosts (5:08) 5. Is It Scary (5:35) 6. Scream Louder (Flyte Tyme Remix) (5:30) 7. Money (Fire Island Radio Edit) (4:23) 8. 2 Bad (Refugee Camp Mix) (3:32) 9. Stranger in Moscow (Tee's In-House Club Mix) (6:54) 10. This Time Around (D.M. Radio Mix) (4:05) 11. Earth Song (Hani's Club Experience) (7:55) 12. You Are Not Alone (Classic Club Mix) (7:37) 13. History (Tony Moran's History Lesson) (8:01)

JACKSON, Michael, Invincible, [disque 33 Tours, cassette, CD], prod. Michael Jackson, Label/ Réf: Epic / Sony EPC 495174 2, sortie 30 octobre 2001.

1. Unbreakable (6:25) 2. Heartbreaker (5:10) 3. Invincible (4:45) 4. Break Of Dawn (5:32) 5. Heaven Can Wait (4:49) 6. You Rock My World (5:39) 7. Butterflies (4:40) 8. Speechless (3:18) 9. 2000 Watts (4:24) 10. You Are My Life (4:39) 11. Privacy (5:05) 12. Don't Walk Away (4:25) 13. Cry (5:01) 14. The Lost Children (4:00) 15. Whatever Happens (4:56) 16. Threatened (4:19)

JACKSON, Michael, Shout, [CD Single, 12", 7"] prod. Michael Jackson, R. Kelly, label Sony, 2001, face B de Cry. 
JACKSON, Michael, Ultimate Collection, [4 CD + 1 DVD], prod. Michael Jackson, Label/Réf: Sony Music Entertainment / BMG Entertainment, sortie 16 novembre 2004.

\section{1 (titres inédits uniquement)}

9.Ease on Down the Road (en duo avec Diana Ross) 11.Shake A Body (Démo) 17. Sunset Driver (chanson inédite non-finalisée)

CD 2 (titres inédits uniquement)

9.Scared of the Moon (chanson inédite) 10. We Are the World (version non-finalisée) 11. We Are Here To Change The World (version studio inédite)

CD 3 (titres inédits uniquement)

7.Cheater (non-finalisée) 8.Dangerous (non-finalisée) 9. Monkey Business (non-finalisée) 14. Someone Put Your Hand Out (non-finalisée)

CD 4 (titres inédits uniquement)

4.On the line 6. Fall again (demo) 11. Beautiful girl (demo) 13. We've had enough

[DVD voir Live in Bucarest]

JACKSON, Michael, This is it, [CD], prod. Michael Jackson \& John McClain, Label/Réf: Jive Epic Group, ASIN : B002Q4U9YU, sortie 26 octobre 2009.

CD1

1. Wanna be startin' somethin' (6:02) 2. Jam (5:39) 3. They don't care about us (4:45) 4. Human nature (4:06) 5. Smooth Criminal (4:17) 6. The way you make me feel (4:59) 7. Shake your body (down to the ground) (3:54) 8. I just can't stop loving you (4:12) 9. Thriller (5:57) 10. Beat it (4:18) 11. Black or white (4:16) 12. Earth song (6:46) 13. Billie Jean (4:54) 14. Man in the mirror (5:20) 15. This is it (album version) (3:37) 16. This is it (orchestra version) (4:55)

$\mathrm{CD} 2$

1. She's out of my life (démo) (3:19) 2. Wanna be startin' somethin' (démo) (5:43) 3. Beat it (démo) (2:05) 4. Planet Earth (3:14)

Hip-hop is read presents: Michael Jackson, The a cappella archive http://www.hiphopisread.com/2009/07/michael-jackson-acapella-archive.html OTHERS

Back on the Block, [CD], prod. Quincy Jones, label Dreamworks, ASIN: B000A2H8WQ, 1989, réed. 9 août 2005

LES PAUL \& MARY FORD, How High the Moon, [78 Tours, 25 cm /10' 78 rpm], Telefunken/Capitol 14660 THE MIRACLES, Who's loving you, [45 Tours], prod. William “Smokey” Robinson, label Tamla T 54034, 27 septembre 1960, face B de Shop around

THE SUPREMES, Who's loving you, [45 Tours], prod. Berry Gordy Jr \& Barney Ales, label Tamla T 54045, juillet et août 1961, face B de Buttered Popcorn

THE JACKSON 5, Who's loving you, [45 Tours], prod. Bobby Taylor, label Tamla Motown 2C006 90927, 7 octobre 1969, face B d' I want you back 


\section{NOTES}

*. Information on the prize: http://volume.revues.org/2592 [editor's note].

1. The story of the song "Who's loving you " is, in this respect, revealing: this one, written in 1960 by Smokey Robinson, had never find a better place than the second one, on B-sides, until the Jackson 5's cover. Talking about break-up, conjugal ill-treatment, guilt, it was not the kind of song to be sing by a ten years old child. But even so, appealed by Michael Jackson's recorded cover, Smokey Robinson asked a meeting with the singer and was so surprised to be in front of a child that he asked to check his identity and his birth date - common thing for the boy, often suspected to be a "dwarf" by his musical opponents during the amateur-musical-competitions he used to take part in Gary and Chicago.

2. Playing on the solid values of its catalogue, Motown financially secured some flagship hits which would then ensure the promotion of a few unreleased songs on each album. Some examples among these covers are hits from Dionne Warwick, Stevie Wonder, the Four Tops, the Supremes, the Temptations, the Miracles, the Isley Brothers, Sly and the Family Stone, Ray Charles, George Clinton, Simon \& Garfunkel, Marvin Gaye, Petula Clark, Funkadelic, Carole King or The Crests

3. The Jacksons (1976), Goin' Places (1977), Destiny (1978), Triumph (1980), Victory (1984), 2300 Jackson Street (1989 Michael Jackson contributes only in the vocal parts of the choruses)

4. The Jacksons, [LP $33 \mathrm{rpm}$, audio cassette, CD], prod. Gamble and Huff / Philadelphia International Records, label Epic, 1976

5. These songs are « Blues away » and « Style of life », album The Jacksons, ibid.

6. THE JACKSONS, GOIN' PLACES, [LP 33 RPM, AUDIO CASSETTE, CD], PROD. GAMBLE AND HUFF / PHILADELPHIA INTERNATIONAL RECORDS, LABEL EPIC ASIN : BO012GNOLW, RELEASED ON OCTOBER $18^{\text {TH }} 1977$.

7. The Wiz, Sydney Lumet's American musical film, released in 1978 ; adapted from the musical produced in Broadway in 1975

8. Seth RIGGS, singing teacher, is the inventor of the «Speech Level Singing », method inspired by the lyrical vocal technique. Having himself pursued a career in Opera and in Music-Hall, he chose, 50 years ago, to teach and had as students singers, actors, dancers, fantasists from the American star system (Ray Charles, Barbara Streisand, Stevie Wonder, Madonna, Prince) or francophone ones (Johnny Hallyday, Sylvie Vartan, Mireille Mathieu). He uses to preside at Master-classes about vocal technique in Colleges and Universities of the whole world and also contributed to medicine, assisting doctors specialized on organic and functional vocal pathologies and participating to the development of vocal therapies.

9. Seth Riggs explained us that he wanted to record an album of lyrical songs with Michael Jackson, because, although he didn't have the perfect technique of a lyrical voice, ha was singing this kind of repertoire in an adapted and surprising way, what we noted when we listened to one of his personal recording of Michael Jackson. Seth Riggs ensured that Michael Jackson was also regularly listening to the tenors Georges Thill, Edmond Clément, the baritone Michel Dens and the coloratura soprano Nathalie Dessay. He worked with him on french works like as «Le rêve » in Manon, « Pourquoi me réveiller, ô souffle du printemps? » in The Tales of Hoffmann, or « Salut ! Demeure chaste et pure » in Gounod's Faust.

10. Michael JACKSON, INVINCIBLE, [LP 33 RPM, AUDIO CASSETTE, CD], PROD. MICHAEL JACKSON, LABEL/REF: EPIC / SONY EPC 495174 2, RELEASED ON OCTOBER $30^{\text {TH }} 2001$.

11. An emblematic example of this sounding head voice is the song «Don't stop 'til you get enough » from off the Wall, op. cit., example we can balance with the falsetto deliberately vaporous of «Fall gain», album Ultimate Collection, [CD 4], prod. Michael Jackson, Label/Ref: Sony Music Entertainment / BMG Entertainment, released on November $16^{\text {th }} 2004$.

12. Quotation often repeated by Bruce Swedien during the different meetings with the author, in Paris and in Florida. 
13. John Robinson, the American pianist and drummer who worked on Off the Wall, explained «He used to record overdubs for each singing part and he used to overlap the layers of singing tracks. The only other person I heard doing so was Chaka Kahn. She's able to do it better than anybody, but Michael was remarkable at this level. I was listening to him singing the third note in a group of four, and I was thinking, referring to my harmonic knowledge from the University of Berkeley that it couldn't work. But, suddenly, he adjusting the fourth note upon all the others and all was sounding perfectly. ", (Cachin, $2009: 22-23$ ).

14. We'll underline this work in the chapter II.4.2.

15. Michael JACKSON, Off the Wall, (Special edition), [CD], prod. Inc, label Epic / Sony ASIN: B0025MOLTG, (1979) released on October $16^{\text {th }} 2001$.

16. Michael JACKSON, Off the Wall, (Special edition) ibid., track 18 "Voice-over Intro Rod Temperton Inteview ». Rod TEMPERTON (Rodney Llyn Temperton) is an english author-composer and arranger, born in 1947; he composed and arranged eight hits for Michael Jackson and worked on the albums off the wall et Thriller.

17. Michael JACKSON, DANGEROUS, [AUDIO CASSETTE, CD], PROD. TEDDY RILEY, MICHAEL JACKSON, LABEL/REF: EPIC / SONY EPC 504424 2, RELEASED ON NOVEMBER $21^{\mathrm{TH}} 1991$

18. Michael Jackson devoted a major part of his time and of his finances to research in this field. He called many sound engineers and technicians upon to develop some original and innovative concepts for that time. Chuck Wild, who worked for long months to design the sounds of the albums HIStory and Blood on the dancefloor, explained us how he responded to Michael Jackson's request, which was, in 1995, about combining and melting concrete, electronic and instrumental sounds in a unique entity, unrecognisable, totally previously unheard, but full of the spirit of the song.

19. The words Beatboxing or Human beatbox evoke the multi-vocal imitation of a beatbox which outcome belongs to the American urban culture with hip-hop. Michael Jackson progressively used this way to express and vocally transcribe his songs as a logical end for his vocal and buccal sounds, till then disparate. The official premises of his beatboxing open the song "Speed demon " on Bad. Therefore, the beatboxing has be used as an important musical component, enhancing and extending the vocal and timbrist polyphony of his songs. But it is, secondly, an important way used by the singer to orally convey his composings to his musicians and engineers, being then able to propose a melodic and rhythmic canvas, almost complete, of the song.

20. Michael JACKSON, SHOUT, [CD SINGLE, 12", 7"] PROD. MICHAEL JACKSON, R. KELLY, LABEL SONY, 2001, B-SIDE OF CRY.

21. Michael JACKSON, HIStory, Past, Present and Future, [CD], prod. Michael Jackson, Label/Ref: Epic / Sony EPC 474709 2, released on June $16^{\text {th }} 1995$, CD 2

22. Michael JACKSON, Thriller, op. cit.

23. Michael JACKSON, Bad, Special Edition [CD], prod. Quincy Jones, Michael Jackson, Label/Ref: Epic / Sony ASIN : B00005NUZO, (1987) released on October $15^{\text {th }} 2001$.

24. Rock and Rap are, indeed, generally in opposition in their principle. Thereby, Rock, which vocally corresponds to hoarse textures similar to acoustic distortion, is linked to instrumental medium, which can be developed in pure musical works, and dismisses the rappers' primary vocality, whom instruments are contained in beatboxes or in samples. On the other side, Rap focuses on vocal expression and often seems to accessorize the musical instrument-tool as much as the social boundary which involves, materially, its acquisition, and symbolically, the access to its practice. (Gilles Boudinet)

25. We can hear it, for example, in «Black or White", album Dangerous, op. cit. In this song, the double-bridge (thought as such with its sixteen bars cut by one bar of break) was, after 18 months worked on the song, the last element to compose, and it was finally thought by Bill Bottrell and 
Michael Jackson as a vocal bridge sustained and reinforced by the rock guitars and followed in its second part by a rap section.

26. Even if Bruce Swedien took part in later projects with Michael Jackson, as the recording of the collective and charity song « What more can I give » in 2003

27. Quote taken from different interviews with the author.

28. Noel Lee, who created in 1979 a society named Monster Cable Products Inc. is engineer in laser fusion in the Laboratory of Lawrence-Livermore, and is also audiophile and professional drummer.

29. Michael JACKSON, Bad, op. cit.

30. Michael Jackson used very often to record the essential of the musical and vocal parts of the songs (but vocally realized), superimposing them, and then providing polyphonic demos a cappella and very developed. A released example is the demo of «Beat it », album This is it, [CD], prod. Michael Jackson \& John McClain, Label/Ref : Jive Epic Group, ASIN : B002Q4U9YU, released on October $26^{\text {th }} 2009$.

31. It is interesting to notice that Sophie Herr and Bruce Swedien consider a same boundary between the concepts of acoustic photography and of vocal personality, firstly, and, secondly, between the concept of acoustic image (Sophie Herr) and of sound image (Bruce Swedien).

32. George Massenburg is a sound engineer, producer and electronic designer.

33. Quotes taken by the author during an interview with Matt Forger in the Westlake Studio in Los Angeles. Matt Forger worked with the artist on several albums like Thriller (1982), E.T. Storyboard (1982), Victory (The Jacksons, 1984), Bad (1987), Dangerous (1991), HIStory (1995), Blood on the dancefloor (1997), and on the music of the short-films Captain Eo (1986) and Ghosts (1996).

34. Suzanne LARNAUDIE, PAUL VALÉRY : RÉFLEXIONS SUR LE CORPS, ASSOCIATION POUR LA DIFFUSION DE LA RECHERCHE LITTÉRAIRE, BOULOGNE, 1988.

35. Word taken to Freud, extract of his Das Unheilmliche, 1919, web link: http:// classiques.uqac.ca/classiques/freud_sigmund/essais_psychanalyse_appliquee/

10_inquietante_etrangete/inquietante_etrangete.pdf

36. Quotes taken by the author during an interview with Bruce Swedien

37. Michael JACKSON, op. cit.

38. Quotes taken by the author during an interview with Bruce Swedien

39. Les Paul \& Mary Ford, "How High the Moon », [78 rpm, 25 cm /10' 78 rpm], Telefunken/ Capitol 14660. Song written by Morgan Lewis (music) and Nancy Hamilton (lyrics) in 1940, recorded in 1949 by Art Tatum for Capitol Records, and then performed by Les Paul and Mary Ford in different shows on TV in 1951.

40. As, for instance, when they featured in the Alistair Cooke's « Omnibus » show, on October $23^{\text {th }}, 1953$.

41. Acoustic Sciences Corporation (ASC) was created by the sound engineer Arthur M. Noxon in 1984. Since, ASC garnered a worldwide reputation in the field of acoustic processing.

42. BLUMLEIN PAIR IS THE NAME GIVEN TO A STEREO RECORDING TEHNIQUE CREATED BY ALAN BLUMLEIN AND AIMING TO RECREATE THE SPATIAL CHARACTERISTICS OF THE RECORDED SIGNAL.

43. Alan Dower BLUMLEIN (JUNE $29^{\mathrm{TH}} 1903$ - JUNE $7^{\mathrm{TH}} 1942$ ), ENGLISH ENGINEER SPECIALIZED IN ELECTRONIC, FAMOUS FOR HIS NUMEROUS INVENTIONS IN THE FIELDS OF TELECOMMUNICATION, SOUND RECORDING, STEREO, TELEVISION AND RADAR SYSTEMS. HE WON 128 AWARDS AND WAS CONSIDERED AS ONE OF THE MOST IMPORTANT ENGINEERS AND INVENTOR OF HIS TIME. HE SET UP THE RECORDING TECHNIQUE NAMED « BINAURAL SOUND » IN 1931.

44. Michael JACKSON, Off the Wall, (Special edition), op. cit.

45. Michael JACKSON, INVINCIBLE, [LP 33 RPM, AUDIO CASSETTE, CD], OP. CIT.

46. Michael JACKSON, Bad, op. cit.

47. Michael JACKSON, HIStory, Past, Present and Future, op. cit.

48. In the words used by the label's director in front of Bruce Swedien at this time. 
49. Bruce Swedien insists on the concept of "stereophonic pair", not to be confused with a recording on two mono channels, confusion visibly widespread in the pop field.

50. Album Back on the Block, [CD], prod. Quincy Jones, label Dreamworks, ASIN: B000A2H8WQ, 1989, new released on August $9^{\text {th }} 2005$. The organization is admittedly acrobatic, but Bruce Swedien uses to say that he loves this kind of exercises.

51. Note that, at this time, with audio digital workstations, the number of tracks is virtually unlimited.

\section{ABSTRACTS}

Michael Jackson was an artist whose many vocal expressions made up the first ground of an eminently pop identity. The aesthetical and eclectic references which inspired and built his vocality had been systematically re-appropriated, re-invested and assimilated in a single vocal personality. Michael Jackson's sound identity, besides its melodic and rhythmic constituents, was built in an audible and tangible way, upon a phenomenon of physicality favoring the oral, guttural, respiratory bruitism of an irrepressible singer, dancing even during the recording sessions. Very concerned about a transparent rendition of this identity, the sound engineer Bruce Swedien opted for some technical approaches and studio strategies aiming at keeping as truly as possible the singer's intimate and natural expressions: mikes, analogic recordings, special techniques elaborated to design vocal prisms, creation of natural acoustic spaces, conversion of stereophonic fields in tri-dimensional sound spaces playing with early reflections, plywood, Monstercable or Tubetraps - each element was deliberately chosen, serving Bruce Swedien's quest of authenticity, including and mixing alternately tradition and technology.

Michael Jackson est un artiste dont les multiples expressions vocales constituent le premier jalon d'une identité paroxystiquement pop. Les références esthétiques éclectiques qui ont échafaudé et nourri sa vocalité se sont trouvées systématiquement réappropriées, réinvesties et assimilées en une seule et même personnalité vocale. L'identité sonore de Michael Jackson, outre ses constituants mélodiques et rythmiques, est construite de façon audible et tangible sur un phénomène de physicalité qui fait la part belle au bruitisme buccal, guttural, respiratoire ou corporel d'un chanteur dansant même en studio. Soucieux de restituer avec transparence cette identité, l'ingénieur du son Bruce Swedien a opté pour des approches techniques et des stratégies de studio visant à conserver fidèlement les expressions premières du chanteur : micros, prises de son analogiques, techniques d'enregistrement des larges prismes vocaux, élaboration d'espaces acoustiques naturels, champ stéréophonique converti en un espace sonore tridimensionnel jouant sur les early reflections, plywood, Monstercable ou encore Tubetraps ont fait l'objet, dans la quête d'authenticité de Bruce Swedien, de choix délibérés convoquant conjointement ou tour à tour tradition et technologie. 


\section{INDEX}

Geographical index: États-Unis / USA

nomsmotscles Jackson (Michael), Swedien (Bruce)

Keywords: studios / home studios, body, voice, key / tone / tonality, harmony, rhythm, recording / editing / production, techniques, sound engineer / editor, beatboxing, dance, intermediaries / mediators, execution / performance / instrumental technique, melody, musical analysis

Chronological index: 1980-1989, 1990-1999, 2000-2009

Subjects: africaine-américaine / African-American music, pop music, soul music, rhythm'n'blues / r'n'b

Mots-clés: studios / home studios, corps, voix, timbre / ton / tonalité, harmonie, rythme, enregistrement / montage / production, techniques, ingénieur son / monteur, beatboxing, danse, intermédiaires / médiateurs, exécution / interprétation / technique instrumentale, mélodie, analyse musicale

\section{AUTHOR}

\section{ISABELLE STEGNER-PETITJEAN}

Isabelle STEGNER-PETITJEAN, est doctorante en musicologie à l'université de Paris IV - Paris Sorbonne où elle rédige actuellement une thèse de doctorat intitulée «Les apports artistiques de Michael Jackson : aspects esthétiques, technologiques et culturels». Cette thèse fait suite à un premier mémoire de Master 2 pour lequel elle a obtenu une mention TB à l'université « Marc Bloch » de Strasbourg et qui portait sur « La personnalité vocale de Michael Jackson: identité, corporalité, syncrétisme ». Professeur certifié bi-admissible, elle enseigne également l'éducation musicale en collège depuis 1997.

mail 